\title{
FAKTOR-FAKTOR YANG BERPENGARUH DALAM KEPUTUSAN PEMBELIAN RUMAH UNTUK MASYARAKAT BERPENGHASILAN RENDAH
}

\author{
Andika Mendrofa ${ }^{1}$, Heri Wibowo ${ }^{2}$, Ivan Sofyan ${ }^{3}$, Taufiq Hendrawan ${ }^{4}$, Wita Witria $^{5}$ \\ ${ }^{1}$ mendrof@yahoo.com, ${ }^{2}$ heriw160978@gmail.com, ${ }^{3}$ ivansofyan77@gmail.com, \\ t.hendrawan@gmail.com, ${ }^{5}$ wwitria2@yahoo.com
}

\section{Program MM Sekolah Bisnis dan Ekonomi Universitas Prasetiya Mulya}

\begin{abstract}
Focus of this research is to study factors influencing the decision-making to purchase houses for low-income communities ("MBR") in which the objective is to find the factors considered by the MBR to purchase a house. The survey covers Jakarta, Bogor, Depok, Tangerang and Bekasi ("Jabodetabek") conducted through online media and direct meeting with 251 respondents (188 respondents is categorized as the MBR and intend to purchase houses). Questionnaire uses Likert Scale with factor and descriptive analysis. Based on result, the considering factors are price, location, promotion, facilities and financing in which the most dominant factors are price and location.
\end{abstract}

Keywords: Price, MBR and factor analysis.

\section{Sari Pati}

Fokus riset ini adalah untuk meneliti faktor-faktor yang berpengaruh dalam keputusan pembelian rumah untuk masyarakat berpenghasilan rendah ("MBR") dimana bertujuan untuk mengetahui faktor-faktor yang dijadikan pertimbangan dalam membeli rumah. Survei riset mencakup wilayah Jakarta, Bogor, Depok, Tangerang dan Bekasi ("Jabodetabek") yang dilakukan secara online dan tatap muka terhadap 251 responden (188 responden dikategorikan sebagai MBR dan berniat membeli rumah). Kuesioner menggunakan Skala Likert dengan analisis faktor dan analisis deskriptif. Berdasarkan hasil riset, faktor-faktor yang menjadi pertimbangan adalah harga, lokasi, promosi, fasilitas dan pembiayaan dimana yang paling dominan adalah harga dan lokasi.

Kata Kunci: Harga, MBR dan analisis faktor. 


\section{PENDAHULUAN}

Pada tanggal 24 Agustus 2016, Pemerintah Indonesia melalui Kementerian Koordinator Bidang Perekonomian mengeluarkan suatu siaran pers mengenai "Rumah Murah Untuk Rakyat" yang menjadi bagian dari Paket Kebijakan Ekonomi XIII dimana bertujuan untuk meningkatkan akses masyarakat untuk mendapatkan rumah.

Untuk mendukung paket kebijakan ekonomi tersebut, Pemerintah Indonesia mengeluarkan Peraturan Pemerintah No. 64 tahun 2016 tentang Pembangunan Perumahan Masyarakat Berpenghasilan Rendah yang diharapkan menjadi payung hukum dalam mempercepat penyediaan perumahan terjangkau bagi MBR. Badan Pusat Statistik (BPS) menyebutkan bahwa sampai dengan Desember 2016, terdapat lebih kurang 11,8 juta keluarga yang belum mempunyai rumah.

Berdasarkan fakta-fakta di atas, peluang untuk pembangunan dan pengembangan perumahan yang terjangkau bagi MBR masih terbuka. Di sisi produsen, produk perumahan yang inovatif diharapkan mampu memenuhi kebutuhan konsumen dan pangsa pasar yang besar. Selain itu, dengan pembangunan dan pengembangan perumahan terjangkau diharapkan dapat memberikan kontribusi sosial kepada negara khususnya untuk MBR.

Dalam makalah ini, kami ingin mengidentifikasi faktor-faktor dominan yang mempengaruhi para calon konsumen khususnya MBR yang berminat untuk membeli rumah di Jabodetabek. Perbedaan makalah ini dengan literatur pada Jurnal Aplikasi Manajemen (JAM) Vol. 14, No. 1 (Maret 2016): 46-57 sebagaimana terindeks dalam Google Scholar adalah pada target konsumen dan cakupan wilayah dimana literatur tersebut meliputi semua konsumen (tidak hanya terbatas pada konsumen MBR) dan hanya meliputi wilayah Palembang. 


\section{TINJAUAN PUSTAKA DAN PENGEMBANGAN PENELITIAN}

\section{Atribut Rumah}

Atribut-atribut rumah yang menjadi dasar preferensi konsumen dalam membeli rumah dapat dibagi dalam dua kategori, yaitu: (i) atribut fisik (terlihat), yang meliputi lokasi, dan fasilitas umum dan fasilitas sosial, dan (ii) atribut non-fisik (tidak terlihat), yang meliputi fasilitas pembiayaan kredit pemilikan rumah (“KPR"), kredibilitas pengembang, promosi dan legalitas. Lokasi

Salah satu faktor yang menjadi pertimbangan utama seseorang memilih rumah adalah kenyamanan bersama dengan kelompok sosial tertentu dimana kelompok ini bisa terbentuk berdasarkan ras, pendapatan, usia dan lain-lain.

Pemilihan lokasi rumah dapat ditentukan dalam beberapa kriteria (Catanese \& Synder 1989), yaitu:

(a) Hukum dan Lingkungan. Hukum yang berlaku memperbolehkan dibangun atau tidak perumahan, ukuran luas bangunan dan tanah, persyaratan jalan, fasilitas sosial dan fasilitas umum.

(b) Sarana. Kebutuhan instalasi air, gas, listrik, telepon, hydrant dan saluran pembuangan.

(c) Faktor Teknis. Topografi, drainase dan curah hujan yang dapat berimplikasi pada desain tempat atau bangunan.

(d) Lokasi. Pemasaran, aksesibilitas, jalur kendaraan umum dan jalur pedestrian.

(e) Estetika. Keindahan rumah/perumahan.

(f) Masyarakat. Dampak pembangunan perumahan terhadap masyarakat sekitar termasuk lalu lintas dan polusi suara.

(g) Fasilitas Pelayanan. Petugas keamanan, pemadam kebakaran, fasilitas pembuangan sampah dan fasilitas pendidikan.

\section{Fasilitas Umum dan Fasilitas Sosial}

Fasilitas umum dapat diartikan sebagai infrastruktur yang dibangun untuk melayani kepentingan umum, antara lain, jalan, saluran air, alat penerangan umum, jaringan listrik, trotoar dan tempat pembuangan sampah. Sedangkan, fasilitas sosial dapat diartikan sebagai infrastruktur yang dibangun untuk menjalankan fungsi sosial dalam masyarakat, antara lain, pusat kesehatan masyarakat (puskemas), sekolah, tempat ibadah, pasar, tempat rekreasi dan makam.

Sifat dasar manusia yang perlu berinteraksi dan menjalin hubungan dengan manusia lain akan cenderung membutuhkan tempat atau sarana publik. Sehingga, dalam kawasan perumahan yang mempunyai jumlah rumah yang banyak, diperlukan fasilitas umum dan fasilitas sosial sebagai wadah para penghuninya untuk berinteraksi dan melakukan kegiatan. Sehingga, masyarakat dalam memilih sebuah kawasan hunian akan mempertimbangkan fasilitas umum dan fasilitas sosial sebagai salah satu faktor yang penting untuk membeli rumah.

\section{Harga}

Salah satu faktor utama seseorang membeli rumah adalah harga. Pada umumnya, atribut ini merupakan pertimbangan awal konsumen dalam memilih dan membeli rumah. 
Kesesuaian harga rumah yang akan dibeli dengan pendapatan per bulan akan merefleksikan seberapa besar rumah dan luas tanah yang didapat, fasilitas yang diperoleh, lokasi dan hal-hal terkait lainnya. Semakin besar pendapatan maka semakin besar ekspektasi atas rumah yang ingin dibeli. Ekspektasi MBR, masyarakat golongan menengah dan masyarakat golongan atas akan berbeda satu sama lain dalam membeli rumah.

\section{Fasilitas Pembiayaan KPR}

Masyarakat memerlukan sistem pembiayaan untuk membantu memperlancar pembelian rumah. Undang-Undang No. 1 Tahun 2011 tentang Perumahan dan Pemukiman secara tegas telah mengatur kewajiban pemerintah untuk memenuhi kebutuhan rumah bagi MBR dengan memberikan kemudahan dan/atau bantuan pembangunan dan perolehan rumah yang dapat berupa, antara lain, subsidi perolehan rumah, insentif perpajakan, penyediaan tanah, sertifikasi tanah dan/atau prasarana, sarana dan utilitas umum.

Saat ini, orientasi pembangunan perumahan untuk MBR lebih menitikberatkan pada pembiayaan yang terjangkau. Apabila sumber pembiayaan yang terjangkau belum tersedia maka masyarakat yang sebenarnya memiliki kapasitas untuk membeli rumah dapat kehilangan kesempatan untuk membeli rumah karena faktor inflasi (dimana daya beli menurun dengan harga rumah yang semakin naik). Dengan demikian, prioritas penyediaan rumah harus dimulai dari memperbaiki sisi permintaan untuk memastikan bahwa MBR benar-benar dapat memiliki daya beli yang efektif (Juniarko et al., 2012).

Fasilitas pembiayaan KPR yang ditawarkan oleh bank ataupun aturan-aturan dari Bank Indonesia sangat berpengaruh bagi masyarakat dalam membeli rumah. Kemudahan administrasi, besaran uang muka dan cicilan menjadi dasar dalam kalkulasi masyarakat dalam mengatasi masalah pembiayaan pembelian rumah. Selain itu, fasilitas kredit perumahan dari lembaga-lembaga pembiayaan lain seperti koperasi dapat menjadi alternatif pembiayaan bagi MBR.

\section{Legalitas}

Legalitas rumah yang akan ditempati menjadi salah satu hal yang penting dalam membeli rumah. Disebutkan bahwa aspek legalitas terkait atribut rumah meliputi legalitas pengembang, legalitas proyek dan legalitas bangunan seperti ijin mendirikan bangunan atau IMB (Kallo 2008)

\section{Kredibilitas Pengembang}

Masyarakat mempertimbangkan kredibilitas developer atau pengembang dalam memilih kawasan perumahan. Pengembang yang terpercaya akan memberikan dampak positif dalam meningkatkan kepercayaan masyarakat tentang pembangunan rumah yang akan mereka tempati.

\section{Promosi}

Ada beberapa cara komunikasi pemasaran perusahaaan, antara lain, iklan, hubungan masyarakat dan tenaga penjual promosi (Ferrel \& Hertline 2011) Promosi yang dilakukan perusahaan pengembang menjadi atribut yang penting untuk menentukan pemilihan 
masyarakat dalam membeli rumah. Kemampuan atribut promosi perusahaan dalam menarik calon pembeli menentukan keberhasilan sebuah kawasan hunian segera terserap pasar atau terbeli oleh masyarakat.

\section{METODOLOGI PENELITIAN}

Populasi

Target responden dalam penelitian ini adalah golongan masyarakat berpenghasilan rendah (dengan penghasilan per bulan di bawah Rp5.000.000) dan yang berniat membeli rumah di wilayah Jabodetabek.

\section{Sampel}

Jumlah responden yang menjadi sampel dalam penelitian ini yang memenuhi kriteria populasi berjumlah 188 responden dari total 251 kuesioner yang diterima.

\section{Teknik Pengumpulan dan Pengolahan Data}

Data yang dikumpulkan adalah data primer dimana pengambilan data dilakukan dengan menyebarkan kuesioner yang berisi pertanyaan-pertanyaan mengenai faktor-faktor yang berpengaruh dalam keputusan pembelian rumah bagi MBR. Atribut-atribut diidentifikasi menggunakan Skala Likert dengan jarak penilaian dari 1 (satu) untuk sikap paling tidak setuju sampai dengan 5 (lima) untuk sikap paling setuju. Kuesioner disebarkan melalui google survey dan secara langsung kepada responden di wilayah Jabodetabek.

\section{Teknik Analisis Data}

Pengolahan data menggunakan teknik analisis faktor (factor analysis) yaitu suatu teknik statistik multivariate untuk mengurangi (reduction) dan meringkas (summarization) semua variabel yang terikat dan saling berketergantungan. Hubungan ketergantungan antara satu variabel dan variabel lain akan diuji untuk diidentifikasikan dimensi atau faktornya.

Maholtra menjelaskan kegunaan analisis faktor (factor analysis), yaitu untuk mengidentifikasi (Maholtra 1996):

(a) dimensi-dimensi atau faktor-faktor yang mendasari hubungan di antara satu set variabel;

(b) suatu variabel/faktor baru yang lebih kecil dan menetapkan variabel-variabel yang semula berhubungan dengan analisis multivarian/analisis regresi atau diskriminan;

(c) tidak tepat kecil variabel penting dari tidak tepat besar variabel untuk digunakan dalam analisis multivarian selanjutnya.

\section{ANALISIS DATA}

Kuesioner yang dibagikan terdiri dari 17 pertanyaan yang merepresentasikan variabel yang merujuk kepada riset sebelumnya. Responden yang mengembalikan kuesioner berjumlah 251 responden dan yang memenuhi syarat sesuai dengan profil MBR berjumlah 188 responden. Data dianalisis menggunakan Statistical Package for the Social Sciences (SPSS) dengan menggunakan kode variabel/pertanyaan dari P1-P17. 


\section{Uji Anti-Image Correlation}

Pertanyaan yang menunjukkan variabel di atas dianalisis pada anti image correlation, dengan mencari variabel dengan angka Measure of Sampling Adequacy (MSA) di atas 0,5. Dari pengujian yang dilakukan dapat diketahui bahwa variabel P1 dan P4 mempunyai anti image di bawah 0,5 sehingga harus dikeluarkan untuk analisa berikutnya.

Matriks Komponen $^{\text {a }}$

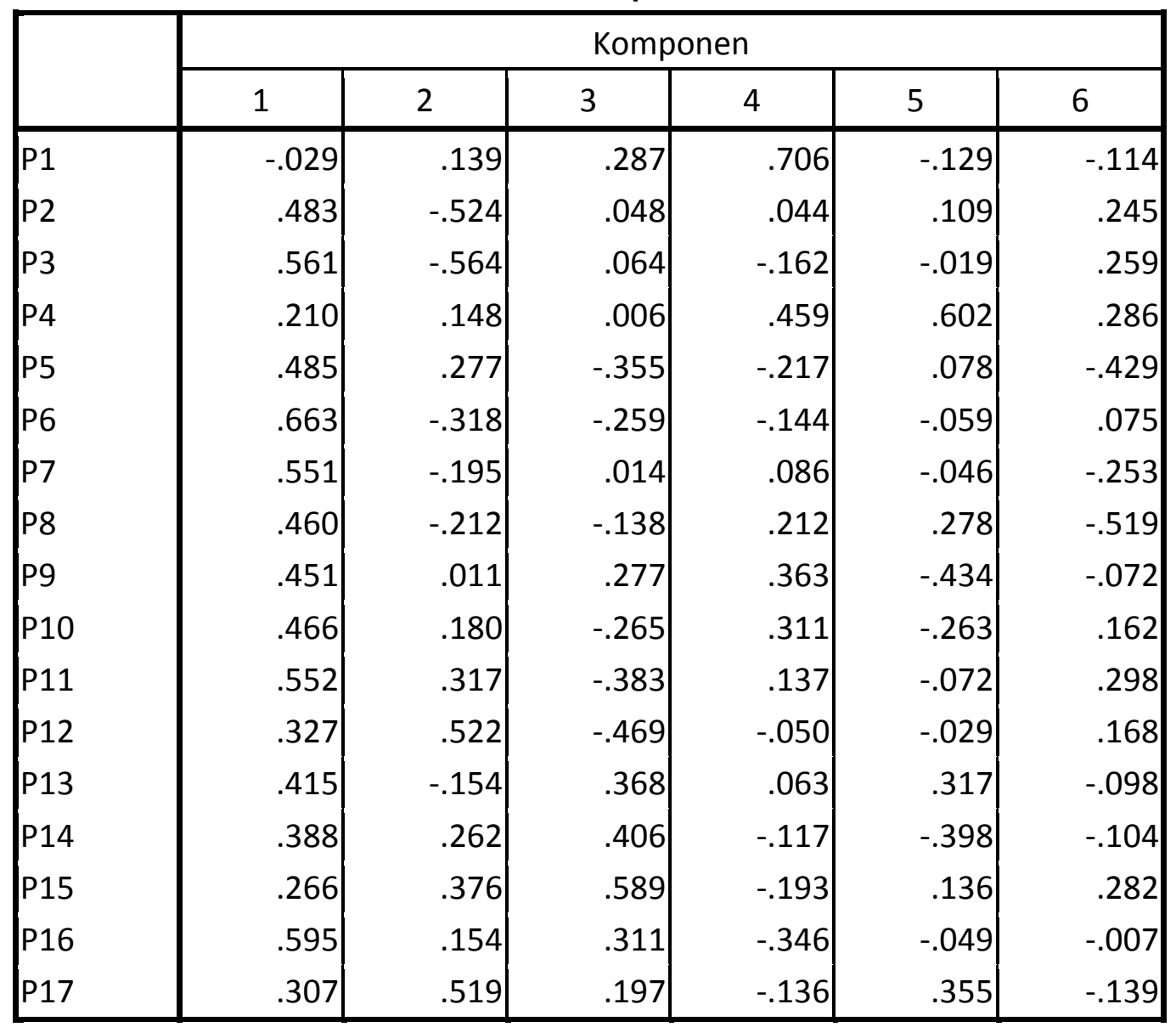

Metode Ekstraksi: Analisis Komponen Prinsipal.

\section{Uji KMO dan Bartlett's Test}

Setelah P1 dan P4 dikeluarkan, dilakukan analisis faktor untuk variabel yang tersisa untuk mendapatkan angka Kaiser-Meyer-Olkin (KMO) di atas 0,5 dengan signifikan 0,000 adalah di bawah 0,05 sehingga variabel dan sampel layak untuk dianalisis lebih lanjut. Hasil analisis faktor yang menghasilkan KMO 0,721 dan Sig. 0,000 adalah sebagai berikut: 


\begin{tabular}{|c|r|}
\hline Kaiser-Meyer-Olkin Measure of Sampling Adequacy & .721 \\
Bartlett's Test of Sphericity Approx. Chi-Square & 547.689 \\
Df & 105 \\
Sig. & .000 \\
\hline
\end{tabular}

\section{Pengujian Analisis Komunalitas}

Secara prinsip, komunalitas dapat diartikan sebagai jumlah varian (dapat dalam suatu persentase) dari suatu variabel mula-mula yang dapat dijelaskan oleh faktor yang ada (Santoso 2002). Dari tabel di bawah, dapat ditemui bahwa untuk P2 didapatkan angka 0,671 yang berarti $67,1 \%$ varian dari variabel harga dapat dijelaskan oleh faktor yang terbentuk. Hal tersebut berlaku juga terhadap variabel-variabel yang lainnya. Faktor yang terbentuk dapat menjelaskan semua variabel dimana semakin besar komunalitas, semakin erat hubungan variabel tersebut dengan faktor yang terbentuk.

\begin{tabular}{|l|r|r|}
\hline \multicolumn{2}{|c|}{ Komunalitas } \\
\hline Zscore(P2) & Inisial & Ekstraksi \\
Zscore(P3) & 1.000 & .671 \\
Zscore(P5) & 1.000 & .745 \\
Zscore(P6) & 1.000 & .595 \\
Zscore(P7) & 1.000 & .637 \\
Zscore(P8) & 1.000 & .443 \\
Zscore(P9) & 1.000 & .588 \\
Zscore(P10) & 1.000 & .618 \\
Zscore(P11) & 1.000 & .575 \\
Zscore(P12) & 1.000 & .612 \\
Zscore(P13) & 1.000 & .641 \\
Zscore(P14) & 1.000 & .508 \\
Zscore(P15) & 1.000 & .488 \\
Zscore(P16) & 1.000 & .654 \\
Zscore(P17) & 1.000 & .541 \\
Zetode & 1.000 & .585 \\
\hline
\end{tabular}

Metode Ekstraksi: Analisis Komponen Prinsipal. 


\section{Pengujian Total Variance Explained}

Penentuan pengelompokan faktor dilakukan berdasarkan pengujian total variance explained dimana 15 (lima belas) variabel yang tersisa dikelompokkan menjadi 5 (lima) faktor berdasarkan angka igenvalues yang menunjukkan lebih besar dari satu.

Total Variance Explained

\begin{tabular}{|c|r|r|r|r|r|r|}
\hline \multirow{2}{*}{ Komponen } & \multicolumn{3}{|c|}{ Initial Eigenvalues } & \multicolumn{2}{|c|}{ Extraction Sums of Squared Loadings } \\
\cline { 2 - 6 } & Total & \% Varian & Kumulatif \% & Total & \% Varian & Kumulatif \% \\
\hline 1 & 3.424 & 22.824 & 22.824 & 3.424 & 22.824 & 22.824 \\
2 & 1.812 & 12.082 & 34.905 & 1.812 & 12.082 & 34.905 \\
3 & 1.571 & 10.473 & 45.378 & 1.571 & 10.473 & 45.378 \\
4 & 1.088 & 7.253 & 52.632 & 1.088 & 7.253 & 52.632 \\
5 & 1.007 & 6.711 & 59.342 & 1.007 & 6.711 & 59.342 \\
6 & .961 & 6.406 & 65.748 & & & \\
7 & .792 & 5.279 & 71.027 & & & \\
8 & .739 & 4.929 & 75.956 & & & \\
9 & .696 & 4.641 & 80.597 & & & \\
10 & .599 & 3.995 & 84.591 & & & \\
11 & .542 & 3.614 & 88.206 & & & \\
12 & .510 & 3.398 & 91.604 & & & \\
13 & .495 & 3.301 & 94.905 & & & \\
14 & .446 & 2.973 & 97.878 & & & \\
15 & .318 & 2.122 & 100.000 & & & \\
\hline
\end{tabular}

Metode Ekstraksi: Analisis Komponen Prinsipal.

\section{Pengujian Scree Plot}

Scree menunjukkan total variance dalam bentuk grafik. Grafik di bawah ini menunjukkan terdapat 5 (lima) faktor yang paling baik yang meringkas ke-15 variabel yang ada. 


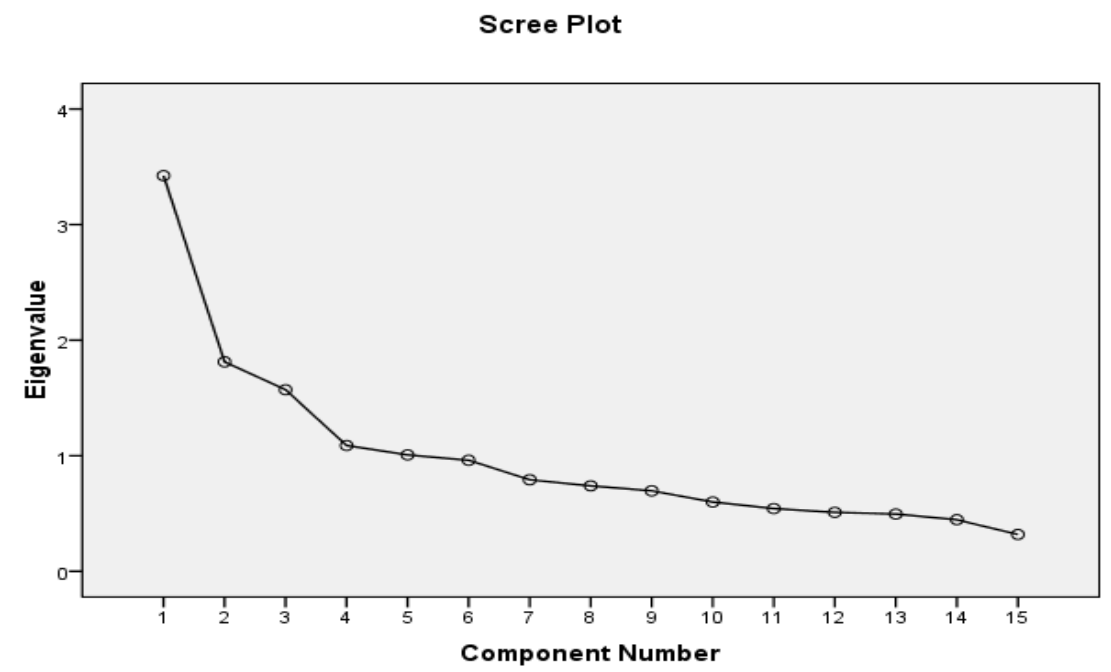

\section{Pengujian Penentuan Variabel Dalam Faktor}

Dalam menentukan variabel yang masuk dalam 5 (lima) faktor yang diidentifikasi dalam analisa total variance explained digunakan component matrix (matriks komponen) dan rotated component matrix.

Dalam tabel matriks komponen di bawah ini, dapat dilihat distribusi 15 (lima belas) variabel dalam 5 (lima) faktor yang terbentuk dan besaran angka di setiap kolom dalam baris variabel menunjukkan besarnya hubungan antara suatu variabel dengan setiap komponen atau faktor 1, faktor 2, faktor 3, faktor 4 atau faktor 5 . Penentuan variabel ke dalam suatu faktor dilakukan dengan melihat angka terbesar dari variabel tersebut di dalam setiap kolom yang mengelompokkan faktor. Sebagai contoh, P2 mempunyai angka paling tinggi dibanding yang lain dan berada di kolom faktor (komponen) 1 sehingga P2 masuk faktor (komponen) 1.

Matriks Komponen $^{a}$

\begin{tabular}{|l|r|r|r|r|r|}
\hline \multirow{2}{*}{} & \multicolumn{6}{|c|}{ Komponen } \\
\cline { 2 - 6 } & 1 & 2 & 3 & \multicolumn{1}{c|}{. } & \multicolumn{1}{|c|}{5} \\
\hline P2 & .483 & -.535 & .009 & .093 & -.377 \\
P3 & .567 & -.547 & .070 & -.013 & -.346 \\
P5 & .488 & .320 & -.311 & .389 & .081 \\
P6 & .669 & -.280 & -.248 & .054 & -.213 \\
P7 & .552 & -.195 & -.010 & -.044 & .314 \\
P8 & .454 & -.226 & -.180 & .321 & .441 \\
P9 & .456 & -.018 & .192 & -.539 & .288 \\
P10 & .465 & .181 & -.311 & -.430 & .211 \\
P11 & .544 & .327 & -.392 & -.170 & -.163
\end{tabular}




\begin{tabular}{|c|c|c|c|c|c|}
\hline P12 & .320 & .550 & -.434 & .002 & -.219 \\
\hline P13 & .413 & -.180 & .355 & .212 & .367 \\
\hline P14 & .395 & .259 & .413 & -.293 & -.093 \\
\hline P15 & .260 & .352 & .640 & .013 & -.230 \\
\hline P16 & .604 & .179 & .369 & .083 & -.032 \\
\hline P17 & 299 & .509 & .241 & .422 & .004 \\
\hline
\end{tabular}

Metode Ekstraksi: Analisis Komponen Prinsipal.

Untuk memperlihatkan distribusi variabel yang lebih jelas digunakan rotated component matrix. Dalam rotated component matrix, angka faktor loading yang kecil akan semakin kecil dan yang besar akan semakin besar sehingga terlihat jelas perbedaannya yaitu untuk memperjelas posisi sebuah variabel pada sebuah faktor.

Rotated Component Matrix

\begin{tabular}{|l|r|r|r|r|r|}
\hline & \multicolumn{5}{|c|}{ Komponen } \\
\cline { 2 - 6 } & 1 & 2 & 3 & 4 & 5 \\
\hline P2 & .810 & -.021 & .038 & .109 & -.023 \\
P3 & .841 & -.047 & .096 & .120 & .112 \\
P5 & .036 & .630 & .113 & .412 & -.125 \\
P6 & .668 & .339 & -.011 & .239 & .134 \\
P7 & .250 & .072 & .047 & .495 & .359 \\
P8 & .163 & .132 & -.128 & .724 & .052 \\
P9 & .080 & -.042 & .205 & .153 & .738 \\
P10 & .023 & .426 & -.063 & .113 & .613 \\
P11 & .186 & .699 & .074 & -.015 & .289 \\
P12 & -.041 & .786 & .083 & -.117 & .035 \\
P13 & .126 & -.196 & .294 & .596 & .110 \\
P14 & .073 & .055 & .579 & -.073 & .372 \\
P15 & .012 & -.036 & .802 & -.095 & .012 \\
P16 & .214 & .157 & .612 & .270 & .151 \\
P17 & -.168 & .324 & .570 & .256 & -.247 \\
\hline
\end{tabular}

Metode Ekstraksi: Analisis Komponen Prinsipal.

Rotation Method: Varimax with Kaiser Normalization.

Mengacu pada rotated component matrix di atas, variabel-variabel pertanyaan yang masuk dalam setiap faktor bisa dikelompokkan sebagai berikut : 


\begin{tabular}{|l|l|l|l|l|}
\hline \multicolumn{5}{|c|}{ Komponen } \\
\hline 1 & \multicolumn{1}{|c|}{2} & \multicolumn{1}{|c|}{3} & \multicolumn{1}{|c|}{4} & \multicolumn{1}{|c|}{5} \\
\hline P2 & P5 & P14 & P7 & P9 \\
\hline P3 & P11 & P15 & P8 & P10 \\
\hline P6 & P12 & P16 & P13 & \\
\hline & & P17 & & \\
\hline
\end{tabular}

\section{Pengujian Component Transformation Matrix}

Analisa diagonal faktor (komponen) dilakukan untuk melihat apakah antara faktor di bawah mempunyai hubungan satu sama lain. Sesuai tabel di bawah ini, dapat dilihat bahwa diagonal faktor (komponen) 1, 2 dan 3 berada di atas 0,5 (yaitu 0,538, 0,589 dan 0,771 ). Hal tersebut dapat membuktikan bahwa ketiga faktor (komponen) mempunyai hubungan yang tinggi sehingga bisa dianggap bahwa faktor itu telah terbentuk dengan benar. Angka di bawah 0,5 untuk diagonal faktor (komponen) 4 dan 5 menunjukkan terdapat faktor (komponen) lain dari faktor tersebut yang mempunyai hubungan cukup tinggi. Jika dilihat pada diagonal faktor (komponen) 4 didapatkan angka 0,497 yang lebih kecil apabila dibandingkan dengan diagonal faktor (komponen) 4 pada faktor 5 sebesar 0,706 yang juga merupakan diagonal faktor yang terbesar dibandingkan dengan faktor (komponen) 1, 2 dan 3. Sebaliknya, untuk diagonal faktor (komponen) 5 ke faktor (komponen) 4 juga didapatkan angka yang lebih besar di 0,856 dibandingkan dengan diagonal faktor (komponen) 5 sebesar 0,349. Berdasarkan analisa tersebut di atas, dapat disimpulkan bahwa faktor 1, faktor 2 dan faktor 3 telah terbentuk dengan tepat karena mempunyai hubungan yang tinggi. Hubungan yang rendah didapatkan dari faktor 4 dan faktor 5 yang mengakibatkan adanya hubungan dengan faktor yang lain. Antara faktor 4 dan 5 terjadi interkorelasi karena hubungan yang tinggi dari kedua faktor tersebut.

Component Transformation Matrix

\begin{tabular}{|l|r|r|r|r|r|}
\hline Komponen & \multicolumn{1}{|c|}{1} & 2 & 3 & 4 & \multicolumn{1}{|c|}{5} \\
\hline 1 & .538 & .447 & .385 & .465 & .381 \\
2 & -.641 & .589 & .452 & -.194 & -.008 \\
3 & -.044 & -.635 & .771 & .013 & .012 \\
4 & .022 & .105 & .093 & .497 & -.856 \\
5 & -.546 & -.196 & -.209 & .706 & .349 \\
\hline
\end{tabular}

Metode Ekstraksi: Analisis Komponen Prinsipal.

Rotation Method: Varimax with Kaiser Normalization.

\section{Penentuan Label Faktor}

Setelah mengidentifikasi faktor-faktor yang terbentuk melalui component tranformation matriks, dapat diketahui variabel yang termasuk dalam setiap faktor berbeda dengan pengelompokan sebelumnya. Sehingga, nama label baru diperlukan agar dapat mencerminkan pengelompokan setiap variabel di dalam masing masing faktor, yaitu sebagai berikut: 
(a) Harga $(22,82 \%)$;

(b) Lokasi $(12,08 \%)$;

(c) Promosi $(10,47 \%)$;

(d) Fasilitas (7,25\%);

(e) Pembiayaan (6,7\%).

Dari penjumlahan varian di atas, didapatkan persentase angka yang masih di bawah $100 \%$. Sehingga, sebenarnya masih terdapat faktor-faktor lain yang berpengaruh yang dapat diungkapkan dengan penelitian lebih lanjut.

\section{KESIMPULAN}

Hal yang bisa menjadi gambaran kecenderungan untuk melihat hubungan setiap faktor adalah jika variabel yang dikelompokkan pada tiap-tiap faktor mempunyai hubungan positif. Jika loading variabel yang terkait semakin besar, kecenderungan faktor tersebut berhubungan akan semakin besar.

Faktor-faktor yang dominan adalah sebagai berikut:

1. Faktor 1, yaitu harga. Hal ini berarti terdapat sekelompok konsumen yang membeli rumah lebih disebabkan oleh faktor harga yang sesuai. Karena hubungan antara harga dan luas bangunan serta tanah dengan rumah yang asri adalah positif, maka dapat disimpulkan bahwa semakin murah namun luas serta asri, akan semakin membuat konsumen tertarik untuk membelinya.

2. Faktor 2, yaitu lokasi. Hal ini berarti terdapat sekelompok konsumen yang memilih lokasi yang mudah dijangkau dan strategis dalam pemilihan perumahan yang akan dibeli.

3. Faktor 3, yaitu promosi. Hal ini berarti terdapat sekelompok konsumen yang lebih banyak mendapatkan informasi tentang rumah melalui internet dan sosial media. Selain itu, promosi melalui pameran juga mendapatkan korelasi yang positif dengan dukungan pelayanan yang komunikatif dari tenaga penjualan perumahan. Dalam faktor ini juga didapati jika rekomendasi pembelian rumah banyak diberikan oleh teman-teman konsumen.

4. Faktor 4, yaitu fasilitas. Hal ini berarti terdapat sekelompok konsumen yang menginginkan keberadaan fasilitas umum yang memadai, seperti jalan, listrik, air dan jaringan telekomunikasi, dan fasilitas sosial, antara lain, tempat ibadah, sekolah dan pasar/pertokoan. Selain itu, dalam faktor fasilitas diketahui bahwa konsumen menginginkan kelengkapan izin mendirikan bangunan (IMB) dan sertifikat rumah dari developer perumahan.

5. Faktor 5, yaitu pembiayaan. Hal ini berarti terdapat sekelompok konsumen yang berpendapat bahwa kemudahan pembiayaan pembelian rumah itu penting dalam pembelian rumah. Hal lain yang mendukung dan terkait dengan pembiayaan adalah besaran uang muka dan cicilan rumah yang terjangkau yang dapat membuat ketertarikan untuk membeli rumah walaupun harga dan lokasi rumah tidak sebaik pilihan lain.

Pada akhirnya, apabila mengacu pada tujuan penelitian yaitu untuk mengetahui faktorfaktor dominan yang mempengaruhi MBR untuk mengambil keputusan membeli rumah di wilayah Jabodetabek, kelima faktor di atas bisa diidentifikasi menjadi faktor yang dominan. 
Hanya saja, dikarenakan persentase varian masih di bawah $100 \%$, tetap terbuka kesempatan dan kemungkinan untuk meneliti faktor-faktor lain yang dominan yang mempengaruhi MBR untuk mengambil keputusan membeli rumah.

\section{DAFTAR PUSTAKA}

Winanto, Agus., Wahab, Zakaria. dan Nazaruddin, Achmad. (2016), “Analisis Preferensi Atribut Terhadap Keputusan Konsumen Membeli Rumah di Kota Palembang", Jurnal Aplikasi Manajemen (JAM), Vol 14, No. 1 (Maret): 46-57.

Ferrell, O.C. dan Michael, D.H. (2011), Marketing Strategy, South Western Cengage Learning Mason, USA.

Indikator Perumahan 1993-2012, Badan Pusat Statistik, 2012.

Kallo, E. (2008), Prespektif Hukum Dalam Dunia Properti, Minerva Athena Pressindo, Jakarta Maholtra, Naresh K. (1996), Marketing Research, An Applied Orientation, NJ, Prentice Hall, Inc. Persentase Rumah Tangga Menurut Propinsi dan Status Kepemilikan Rumah Sendiri 1993-2012, Badan Pusat Statistik, 2012.

Santoso, Singgih. (2002) , SPSS Statistik Multivariat, PT Alex Media Komputerindo, Jakarta. Undang - Undang Republik Indonesia Nomor 1 Tahun 2011 tentang Perumahan dan Kawasan Permukiman. 


\section{LAMPIRAN}

Kuesioner

NO :....

\section{LEMBAR KTESIONER}

Kapads Yth:

Bpkithe, Stri

Di temprat.

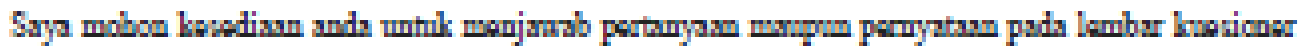
magani "Analisis Preferensi Atribut terhadap Keputusan Konsumen Membeli Rumah Murah Sederhana di JABODETABEK:

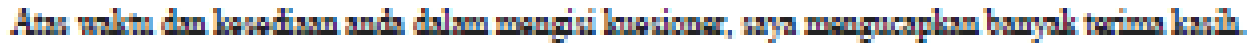

\section{IDENTIAS RFSPONDEN}

1) Budan

Uinur talhun

Jois Ralamin : Laki-labi / Porsmpun

Panditikn :

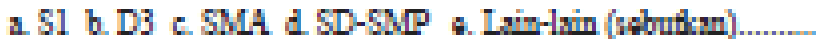

Pakajasn

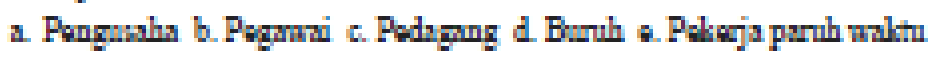
Laim-lin (vabuttan]........

Stus pamilahan:

a. Balmm Manikh b. Mewiksh c. Janda (carai/maningpol) d. Doh (carailmaningal)

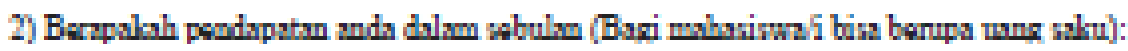

a. $=$ Rp. 1.50000

b. R. $1.500 .00-$ R. 2.500 .00

c. Ap $2 \% 0000-\mathrm{Bp} 500000$

$\mathrm{d}=\mathrm{Rp} \cdot 5000.00$

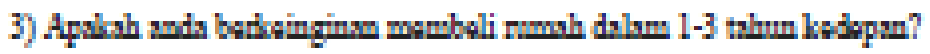

a. Ya b. Tidal: 


\section{PETUNJK PENGISLAN}

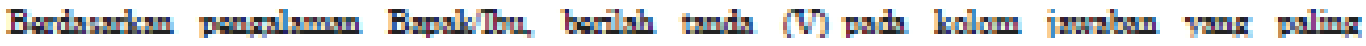

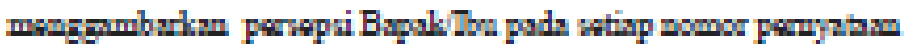

Eatorangun Jawabur

SS : Snot Satan:

$5 \quad$ : Striju

R. : Ragaragu

IS :Tidak Sqün

STS : Sungat Titak Sotuin

1.FAKTOR HARGA

\begin{tabular}{|c|c|c|c|c|c|c|}
\hline \multirow[b]{2}{*}{ no } & \multirow[b]{2}{*}{ PERTAMYAN } & 55 & 5 & $\overline{\mathbf{R}}$ & TS & STS \\
\hline & & 5 & 4 & 3 & 2 & 1 \\
\hline 1. & 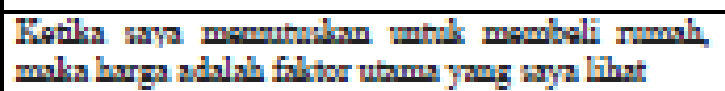 & & & & & \\
\hline 2. & 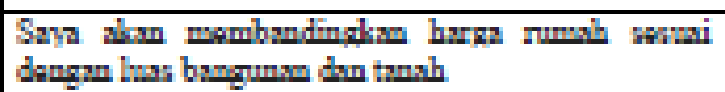 & & & & & \\
\hline 3. & 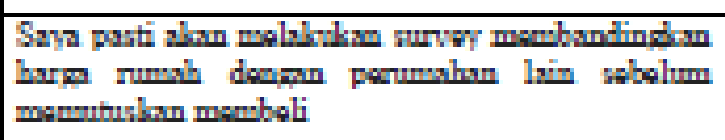 & & & & & \\
\hline 4 & 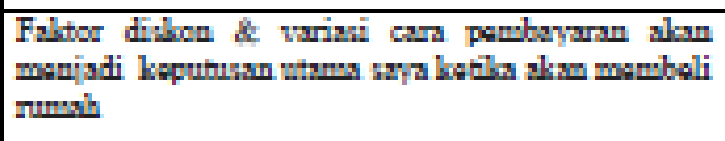 & & & & & \\
\hline
\end{tabular}

\section{FAKTOR LOKASI}

\begin{tabular}{|c|c|c|c|c|c|c|}
\hline \multirow[b]{2}{*}{ No } & \multirow[b]{2}{*}{ PERTAMYAY } & $5 S$ & 5 & $\mathbb{R}$ & TS & $5 \mathrm{SS}$ \\
\hline & & 5 & 4 & 3 & 2 & 1 \\
\hline 1 & 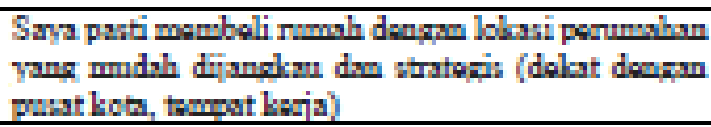 & & & & & \\
\hline 2 & 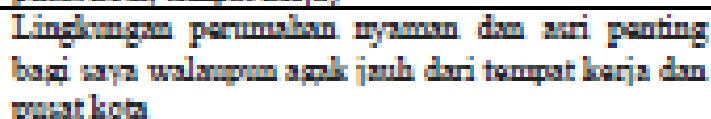 & & & & & \\
\hline
\end{tabular}

\section{FAKTOR FASTIMAS IDIMIDAN SOSLA}

\begin{tabular}{|c|c|c|c|c|c|c|}
\hline \multirow[b]{2}{*}{ No } & \multirow[b]{2}{*}{ PERTAMYAY } & 55 & 5 & $\mathbf{R}$ & TS & STS \\
\hline & & 5 & 4 & 3 & 2 & 1 \\
\hline 1 & 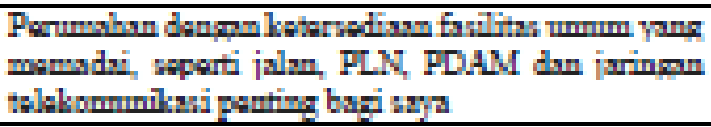 & & & & & \\
\hline 2 & 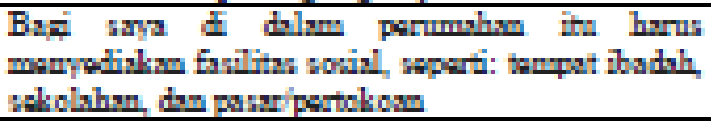 & & & & & \\
\hline
\end{tabular}




\begin{tabular}{|c|c|c|c|c|c|c|}
\hline \multirow[b]{2}{*}{ No } & \multirow[b]{2}{*}{ PERTANYALAN } & SS & 5 & $\mathbf{E}$ & Ts & STS: \\
\hline & & 5 & 4 & 3 & 2 & $\overline{1}$ \\
\hline$I$ & 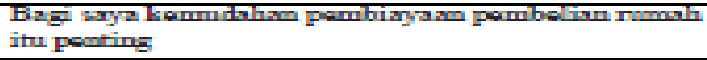 & & & & & \\
\hline 2 & 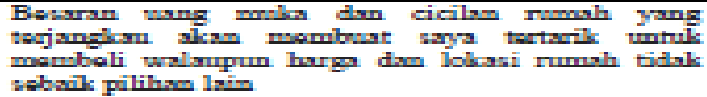 & & & & & \\
\hline 3 & 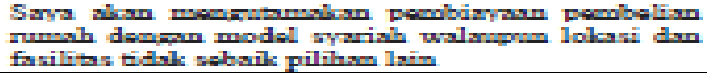 & & & & & \\
\hline
\end{tabular}

\begin{tabular}{|c|c|c|c|c|c|c|}
\hline \multirow[b]{2}{*}{ No } & \multirow{2}{*}{ PERTANYAAN } & 55 & 5 & $\mathbf{F}$ & TS & STS \\
\hline & & 5 & 4 & 3 & 2 & $\mathbb{1}$ \\
\hline 1 & 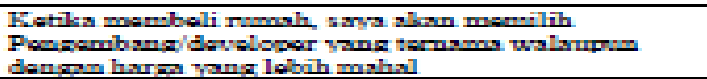 & & & & & \\
\hline 2 & 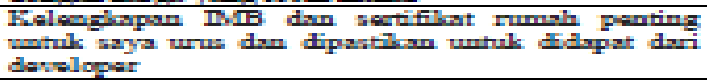 & & & & & \\
\hline
\end{tabular}

\begin{tabular}{|c|c|c|c|c|c|c|}
\hline \multirow[b]{2}{*}{ NO } & \multirow{2}{*}{ FERTARYALA } & 55: & 5 & $\overline{\mathbf{R}}$ & TS & STS \\
\hline & & 5 & 4 & 3 & 2 & 1 \\
\hline I & 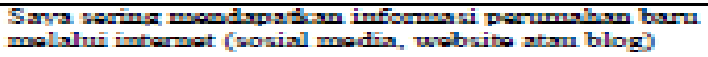 & & & & & \\
\hline 2 & 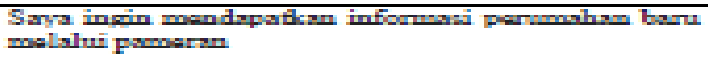 & & & & & \\
\hline 3 & 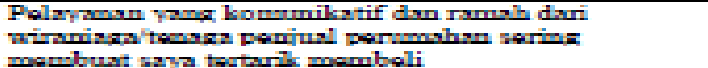 & & & & & \\
\hline 4 & 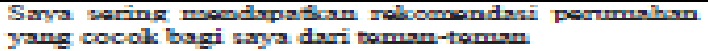 & & & & & \\
\hline
\end{tabular}

\section{$\underline{\text { Responden }}$}

\begin{tabular}{l} 
Row Labels Count of Apakah anda berkeinginan membeli rumah dalam 1-3 tahun kedepan? \\
Tidak \\
Ya \\
\hline Grand Total \\
$\qquad$\begin{tabular}{ll}
\hline $17 \%$ \\
\hline
\end{tabular} \\
\hline
\end{tabular}

